\title{
Use of androgenic anabolic steroids by patients under treatment for substance use disorder: case series
}

\author{
Uso de esteroides androgênicos anabolizantes por pacientes em \\ tratamento para transtorno por uso de substâncias: relato de casos \\ Julio Mario Xerfan do Amaral', Marcelo Santos Cruz'
}

\begin{abstract}
The present study reports several case studies about the use of androgenic-anabolic steroids (AAS) by patients under treatment for substance use disorder (SUD). Ten subjects were interviewed, two women and eight men, ranging from 25 to 43 years old. Regarding treatment regime, eight subjects were inpatients and two, outpatients. ASSIST-WHO and MINI-SUD scales and a semi-structured interview were used as research instruments. Seven subjects reported the use of AAS within fewer than twelve months from the interview date. Mental health professionals did not previously question none of the subjects were about the use of AAS. We discuss the efficacy of the chosen instruments to assess AAS use.
\end{abstract}

\section{Keywords}

Anabolic agents, steroids, substance-related disorders.

\section{Palavras-chave}

Anabolizantes, esteroides, transtornos relacionados ao uso de substâncias.

\section{RESUMO}

Este artigo apresenta uma série de casos relatando o uso de esteroides androgênicos anabolizantes (EAA) por pacientes em tratamento para transtorno por uso de substâncias (TUS). Dez sujeitos foram entrevistados, sendo duas mulheres e oito homens, de 25 a 43 anos de idade. Oito sujeitos encontravam-se em regime de internação e dois sujeitos, em tratamento ambulatorial. Os instrumentos da pesquisa foram as escalas ASSIST-OMS e MINI-TUS, além de uma entrevista semiestruturada. Sete sujeitos informaram o uso de EAA há menos de doze meses da entrevista. Nenhum dos sujeitos havia sido questionado anteriormente sobre o uso de EAA por algum profissional de saúde mental. Discutimos a eficácia das escalas escolhidas em avaliar o uso de EAA.
1 Program of Study and Assistence of Drug Abuse (PROJAD), Psychiatry Institute, Federal University of Rio de Janeiro (IPUB-UFRJ).

\author{
Address for correspondence: Julio Mario Xerfan do Amaral \\ Rua Dezesseis de Março, 354/905 \\ 25620-040 - Petrópolis, RJ, Brazil \\ Telephone: (+55 24) 2225-9206 \\ E-mail:jxerfan@yahoo.com
}




\section{INTRODUCTION}

Androgenic-anabolic steroids (AAS) - i.e.,the natural hormone testosterone and its synthetic relatives - are substances with both androgenic (responsible for developing and maintaining male characteristics) and anabolic (responsible for stimulating muscle hypertrophy) properties.

According to the US Food and Drug Administration (FDA), "testosterone is a FDA-approved replacement therapy only for men with testicle, pituitary gland, or brain disorders that cause hypogonadism '". Therefore, the use of testosterone in the absence of these clinical conditions must be considered a misuse of AAS.

The misuse of AAS has been growing among men and women, and the majority of AAS users are no longer elite athletes, which was the case until the $1980 \mathrm{~s}^{2}$.

The use of AAS has well known adverse effects, namely to the cardiovascular system ${ }^{3}$, endocrine system ${ }^{4}$, and liver ${ }^{5}$. Other effects include acne, baldness, and an increased risk of muscle and joint lesions due to overtraining ${ }^{6}$. Regarding behavioural and psychiatric effects, AAS users are at greater risk than non-users to suffer from manic symptoms, such as irritability, aggressive behaviour, euphoria, delusions of grandeur, insomnia, hyperactivity, and reckless attitudes, 7.8 . AAS also play a central role in muscle dysmorphia (an obsessive concern about the body, including a false belief that one's own body is insufficiently muscular) and the pathological manipulation of body image ${ }^{9}$. AAS use is a risk factor for substance use disorder (SUD), and possibly the other way round is also true ${ }^{10,11}$. Most AAS users never report its use or seek help to stop using it². Mental health professionals tend to be less familiar with AAS than they are with other substances of abuse $\mathrm{e}^{12}$.

The objectives of the present study were: (a) to describe reports on AAS misuse by patients under treatment for SUD; (b) to identify associations between AAS misuse concurrent to other substances; (c) to test whether, in the subject's perception, AAS use is considered a relevant issue in their SUD treatment; and (d) to discuss whether the psychometric scales used to assess AAS misuse in the present study are efficient for this purpose.

\section{METHODS}

Inclusion criteria for the present study comprised patients under treatment for SUD, who answered positively to the question 'have you ever used AAS?', above 18 years old, who were able to answer the questionnaires, accepted to take part in the study, and signed the informed consent form. Subjects answered a semi-structured interview, the International Neuropsychiatric Interview (MINI) modules $J$ and $\mathrm{K}^{13}$, and the World Health Organization's Alcohol, Smoking, and
Substance Involvement Screening Test (ASSIST) ${ }^{14}$. The present study is registered at the Brazilian Committee for Ethics in Research under CAAE: 62760716.2.0000.5263.

\section{RESULTS}

Ten subjects under treatment for SUD were interviewed; eight under inpatient treatment (IT) at Revitalis Clinic and two under outpatient treatment (OT) at PROJAD-UFRJ. Interviews were obtained from November 2016 to January 2017 in Rio de Janeiro, Brazil.

Reinforcing effects of AAS were similar among subjects (increase in disposition and stamina, focus on physical training, quick and intense muscle hypertrophy). Motivations for the use of AAS included low self-esteem, desire to lose weight, to look better or become more muscular. Subjects that abandoned the use of AAS did so allegedly due to the reported side effects. Those subjects referred to the same symptoms of AAS withdrawal, which included quick loss of muscle mass, weight gain, and mild depression.

\section{CASE REPORTS}

Subject 1 is a 39-year-old female under IT for SUD (alcohol). Adverse effects (AE) of AAS included deepening in voice tone, abnormal hair growth on the face and body, hair loss, irritation, and insomnia. Sleep disturbance stimulated alcohol consumption, along with the unprescribed use of clonazepam, diazepam, and midazolam. The subject has been using AAS for 15 years, and the last use occurred 21 days before the interview.

Subject 2 is a 25-year-old female, under IT for SUD (sedatives). AE of AAS included acne, abnormal hair growth on the face and body, increase in aggressive behaviour, and insomnia. Sleep disturbance led to the misuse of clonazepam. The subject reported a frequent loss of control over food ingestion, leading to a relapse in the use of AAS to lose weight and, eventually, she prostituted herself. The subject has been using AAS for three years, and the last use occurred nine months before the interview.

Subject 3 is a 38-year-old male, under IT for SUD (alcohol and cocaine). AE of AAS included acne, tachycardia, and agitation. He used AAS for less than one year, and the last use occurred 20 years before the interview.

Subject 4 is a 38-year-old male, under IT for SUD (alcohol and cocaine). AE of AAS included water retention, aggressiveness, left ventricular hypertrophy, hypertension, erectile dysfunction, transitory testicular atrophy, and insomnia. He used AAS for five years, and the last use occurred 15 years before the interview. 
Subject 5 is a 35-year-old male, under IT for SUD (cocaine). AE of AAS included hair loss, increase of skin oiliness, increase in liver enzymes, dyslipidaemia, joint lesions due to overtraining, aggressiveness, irritation, and insomnia. Sleep disorders led to misuse of clonazepam. Subject relapsed on cocaine after an AAS cycle. He has been using AAS for four years, and the last use occurred five months before the interview.

Subject 6 is a 43-year-old male, under IT for SUD (cocaine and clonazepam). AE of AAS included fatigue, erectile dysfunction, diffuse abdominal pain, deep vein thrombosis, aggressiveness, and "a difficulty to control his anger" that persists today. He used AAS for 14 years, and the last use occurred 17 years before the interview.

Subject 7 is a 47-year-old male, under IT for SUD (cocaine). No AE were reported. The subject 7 has been HIVpositive for the last 12 years. A physician prescribed this AAS due to severe weight loss attributed to his HIV condition.
The subject informed an intention of using extra doses of AAS to obtain faster results and that his relapse on cocaine followed his last AAS cycle. He has been using AAS for 2 years, and the last use occurred two months before the interview.

Subject 8 is a 40-year-old male, under IT for SUD (cocaine). AE of AAS included anxiety, aggressiveness, impatience, insomnia, "change in personality and decision-making". The subject has been HIV-positive for the last five years. He has been using AAS for 23 years, and the last use occurred three months before the interview.

Subject 9 is a 27-year-old male, under OT for SUD (cannabis). AE of AAS included hallucination symptoms (voices and commands). He has been using AAS for five years, and the last use occurred two months before the interview.

Subject 10 is a 20-year-old male, under OT for SUD (ecstasy, cocaine, crack, and inhalants). AE of AAS included impatience and halitosis. He has been using AAS for two years, and the last use occurred three weeks before the interview.

Table 1. Subject's perception on the use of AAS and results of screening scales

\begin{tabular}{|c|c|c|c|c|c|c|c|c|c|c|}
\hline Subject & $\begin{array}{l}\text { AAS are good } \\
\text { or bad for your } \\
\text { health? }\end{array}$ & $\begin{array}{l}\text { Is it possible } \\
\text { to use AAS in a } \\
\text { safe way? }\end{array}$ & $\begin{array}{l}\text { Is it possible } \\
\text { for one to } \\
\text { become } \\
\text { addicted in } \\
\text { AAS? }\end{array}$ & $\begin{array}{l}\text { Are you } \\
\text { addicted in } \\
\text { AAS? }\end{array}$ & $\begin{array}{l}\text { Are you } \\
\text { satisfied with } \\
\text { your body } \\
\text { image today? }\end{array}$ & $\begin{array}{l}\text { Do you intend } \\
\text { to use AAS } \\
\text { again? }\end{array}$ & AAS using time & Last AAS use & $\begin{array}{l}\text { MINI-SUD (abuse/ } \\
\text { dependence) }\end{array}$ & $\begin{array}{l}\text { ASSIST-OMS } \\
\text { (brief/intensive } \\
\text { intervention) }\end{array}$ \\
\hline $1(\mathrm{~F}, 39 \mathrm{y})$ & Bad & Yes & Yes & Yes & Yes & Yes & $15 y$ & $21 \mathrm{~d}$ & $\begin{array}{l}\text { AAS, alcohol, } \\
\text { sedatives, } \\
\text { stimulants }\end{array}$ & $\begin{array}{l}\text { Brf: stimulants } \\
\text { Int: AAS, alcohol, } \\
\text { sedatives, tobacco }\end{array}$ \\
\hline $2(F, 25 y)$ & Bad & No & Yes & Yes & No & Yes & $3 y$ & $9 m$ & $\begin{array}{l}\text { AAS, alcohol, } \\
\text { cocaine, cannabis, } \\
\text { sedatives, } \\
\text { stimulants }\end{array}$ & $\begin{array}{c}\text { Brf: cannabis, } \\
\text { tobacco, stimulants } \\
\text { Int: alcohol, } \\
\text { cocaine, sedatives }\end{array}$ \\
\hline $3(M, 38 y)$ & Bad & No & Yes & No & Yes & No & $<1 y$ & $20 y$ & $\begin{array}{l}\text { alcohol, cocaine, } \\
\text { sedatives }\end{array}$ & $\begin{array}{l}\text { Brf: sedatives } \\
\text { Int: alcohol, } \\
\text { cocaine }\end{array}$ \\
\hline $4(M, 38 y)$ & Bad & Yes & Yes & No & No & Yes & $5 y$ & $15 y$ & alcohol, cocaine, & $\begin{array}{l}\text { Brf: tobacco } \\
\text { Int: alcohol, } \\
\text { cocaine }\end{array}$ \\
\hline $5(M, 35 y)$ & Bad & Yes & Yes & Yes & No & No & $4 y$ & $5 \mathrm{~m}$ & $\begin{array}{l}\text { AAS, alcohol, } \\
\text { cocaine }\end{array}$ & $\begin{array}{c}\text { Brf: AAS, sedatives } \\
\text { Int: cocaine, } \\
\text { tobacco }\end{array}$ \\
\hline $6(M, 43 y)$ & Bad & Yes & Yes & No & Yes & Maybe & $14 y$ & $17 y$ & $\begin{array}{l}\text { alcohol, cocaine, } \\
\text { sedatives }\end{array}$ & $\begin{array}{l}\text { Brf: alcohol, } \\
\text { sedatives, tobacco } \\
\text { Int: cocaine }\end{array}$ \\
\hline $7(M, 47 y)$ & Good & Yes & Don't know & No & Yes & Yes & $2 y$ & $2 \mathrm{~m}$ & cocaine & Int: cocaine \\
\hline $8(M, 40 y)$ & Good & Yes & Yes & Yes & Yes & Yes & $23 y$ & $3 \mathrm{~m}$ & $\begin{array}{l}\text { AAS, cocaine, } \\
\text { cannabis }\end{array}$ & $\begin{array}{l}\text { Brf: stimulants } \\
\text { Int: cocaine, } \\
\text { cannabis }\end{array}$ \\
\hline $9(M, 27 y)$ & Good & Yes & Yes & No & Yes & Not sure & $5 y$ & $2 m$ & alcohol, cannabis & $\begin{array}{l}\text { Brf: AAS, alcohol, } \\
\text { cannabis, tobacco }\end{array}$ \\
\hline $10(\mathrm{M}, 20 \mathrm{Y})$ & Good & Yes & Yes & No & No & Yes & $2 y$ & $3 w$ & AAS, cocaine & $\begin{array}{l}\text { Brf: AAS, cannabis, } \\
\text { hallucinogens, } \\
\text { inhalants } \\
\text { Int: cocaine }\end{array}$ \\
\hline
\end{tabular}

F: female; M: male; y: years old; m: months; w: weeks; d: days; Brf: brief intervention recommended; Int: intensive intervention recommended. 


\section{DISCUSSION}

None of the subjects has ever considered AAS use to be part of their substance use disorder. Additionally, they have informed that their use of AAS has never been questioned previously - which is subject to a recall bias. That perception seems aligned with the information from previous studies, in which AAS misuse may be an overlooked condition 2,6,15.

Regarding the assessment of AAS misuse by MINISUD and WHO-ASSIST, our findings suggest that some characteristics of AAS may have compromised its screening by those instruments. For instance, AAS are used in cycles that may vary in frequency, so that a regular user may be free from AAS for more than a year at the time of the interview. Besides, exceptional amounts of time spent in physical activities (which are considered a healthy practice) may not be perceived as a problem by AAS users.

We acknowledge several limitations to our study. The small number of subjects prevents epidemiologic conclusions. There was no access to data regarding clinical dysfunctions previously experienced by the subjects. Finally, the type and doses of AAS allegedly used could not be verified.

\section{CONCLUSIONS}

Our findings suggest that the abuse of AAS may complicate a case of SUD, as AAS users tend to become dependent on escalating doses of those substances. Besides, common adverse effects of AAS, such as insomnia and agitation, might prompt (or increase) the misuse of substances, such as sedatives and alcohol. Additionally, manic-like effects of AAS may lead to poor risk perception and abuse of other substances.

We believe that by investigating the use of AAS and addressing issues related to it - body image, eating disorders, and self-esteem - mental health professionals might offer a more effective treatment to SUD patients with a history of AAS use, which could prevent relapses and protect them from the adverse effects of AAS.

\section{INDIVIDUAL CONTRIBUTIONS}

Julio Mario Xerfan do Amaral - Study's conception and design, interview of subjects, data analysis, article's draft, and final approval.

Marcelo Santos Cruz - Study's conception and design, data analysis, article's revision, and final approval.

\section{CONFLICTS OF INTEREST}

Julio Mario Xerfan do Amaral and Dr. Marcelo Santos Cruz have no conflicts of interest to report.

\section{REFERENCES}

1. US Food and Drug Administration. FDA Drug Safety Communication. [FDA web site]. 2014. Available at: https://www.fda.gov/Drugs/DrugSafety/ucm436259.htm. Accessed on: Feb. $18,2017$.

2. Kanayama G, Hudson Jl, Pope HG Jr. Long-term psychiatric and medical consequences of anabolic-androgenic steroid abuse: a looming public health concern? Drug Alcohol Depend. 2008;98(1-2):1-12.

3. Do Carmo EC, Fernandes T, Koike D, Da Silva ND Jr, Mattos KC, Rosa KT, et al. Anabolic steroid associated to physical training induces deleterious cardiac effects. Med Sci Sports Exerc. 2011;43(10):1836-48.

4. Fortunato RS, Rosenthal D, Carvalho DP. Steroids abuse and impact on thyroid function. Arq Bras Endocrinolol Metab. 2007;51(9):1417-24.

5. Gorayski P, Thompson CH, Subhash HS, Thomas AC. Hepatocellular carcinoma associated with recreational anabolic steroid use. Br J Sports Med. 2008;42(1):74-5.

6. Reardon LC, Creado S. Drug abuse in athletes. Subst Abuse Rehabil. 2014;5:95-105.

7. Chapman MJ, Hall RCW, Hall RW. Psychiatric complications of anabolic steroid abuse. Psychosomatics. 2005;46(4):285-90.

8. Pope HG, Katz DL. Psychiatric and medical effects of anabolic-androgenic steroid use: a controlled study of 160 athletes. Arch Gen Psychiatry. 1994;51(5):375-82.

9. Pope HG Jr, Gruber AJ, Choi P, Olivardia R, Phillips KA. Muscle dysmorphia. An underrecognized form of body dysmorphic disorder. Psychosomatics. 1997;38(6):548-57.

10. Kanayama G, Pope HG, Cohane G, Hudson JI. Risk factors for anabolic-androgenic steroid use among weightlifters: a case-control study. Drug Alcohol Depend. 2003;71(1):77-86.

11. Dodge T, Hoagland MF. The Use of Anabolic Androgenic Steroids and Polypharmacy: A Review of the Literature. Drug Alcohol Depend. 2011;114(2-3):100-9.

12. Reardon CL, Factor RM. A systematic review of diagnosis and medical treatment of mental illness in athletes. Sports Med. 2010;40(11):961-80.

13. Amorim P. Mini International Neuropsychiatric Interview (MINI): validation of a short structured diagnostic psychiatric interview. Rev Bras Psiquiatr. 2000;22-3:106-15.

14. Humeniuk R. Validation of the Alcohol, Smoking and Substance Involvement Screening Test (ASSIST) and pilot brief intervention: a technical report of phase II findings of the WHO ASSIST Project. World Health Organization, 2006.

15. Pope HG, Kanayama G, lonescu-Pioggia M, Hudson Jl. Anabolic steroid users' attitudes towards physicians. Addiction. 2004;99(9):1189-94. 